\title{
What Is Expected from a Facial Trauma Caused by Violence?
}

\author{
Douglas Rangel Goulart ${ }^{1}$, Lucas do Amaral Colombo ${ }^{2}$, Márcio de Moraes ${ }^{1}$, Luciana Asprino \\ ${ }^{1}$ Division of Oral and Maxillofacial Surgery, FOP-UNICAMP, Piracicaba, São Paulo, Brazil. \\ ${ }^{2}$ Piracicaba Dental School, UNICAMP, São Paulo, Brazil.
}

\author{
Corresponding Author: \\ Douglas Rangel Goulart \\ Division of Oral and Maxillofacial Surgery \\ FOP-UNICAMP \\ Av Limeira 902 - Box 22, 14900-414, Piracicaba, São Paulo \\ Brazil \\ Phone: +55 1921065390 \\ Fax: +55 1921065389 \\ E-mail: douglasrgoulart@gmail.com
}

\section{ABSTRACT}

Objectives: The aim of this retrospective study was to compare the peculiarities of maxillofacial injuries caused by interpersonal violence with other etiologic factors.

Material and Methods: Medical records of 3,724 patients with maxillofacial injuries in São Paulo state (Brazil) were retrospectively analyzed. The data were submitted to statistical analysis (simple descriptive statistics and Chi-squared test) using SPSS 18.0 software.

Results: Data of 612 patients with facial injuries caused by violence were analyzed. The majority of the patients were male $(81 \% ; n=496)$, with a mean age of 31.28 years (standard deviation of 13.33 years). These patients were more affected by mandibular and nose fractures, when compared with all other patients $(\mathrm{P}<0.01)$, although fewer injuries were recorded in other body parts $\left(\chi^{2}=17.54 ; \mathrm{P}<0.01\right)$; Victims of interpersonal violence exhibited more injuries when the neurocranium was analyzed in isolation $\left(\chi^{2}=6.85 ; \mathrm{P}<0.01\right)$.

Conclusions: Facial trauma due to interpersonal violence seem to be related to a higher rate of facial fractures and lacerations when compared to all patients with facial injuries. Prominent areas of the face and neurocranium were more affected by injuries.

Keywords: aggression; epidemiology; mandibular injuries; maxillofacial injuries.

Accepted for publication: 15 December 2014

To cite this article:

Goulart DR, Colombo LA, de Moraes M, Asprino L. What Is Expected from a Facial Trauma Caused by Violence?

J Oral Maxillofac Res 2014;5(4):e4

URL: http://www.ejomr.org/JOMR/archives/2014/4/e4/v5n4e4ht.pdf

doi: $10.5037 /$ jomr.2014.5404 


\section{INTRODUCTION}

The quantity of trauma victims and the management involved in attending them leads to a great workload in most hospitals and places an enormous amount of pressure on the health care system [1]. Furthermore, traumatic injuries have been reported as the leading cause of death in the first 40 years of life and appear to be on the increase [2]. During the last decade, interpersonal violence (IPV) was one of the main etiological factors of fractures of the maxillofacial complex [3]. Road traffic accidents remain the most important cause of maxillofacial trauma worldwide, although falls and assaults have become more significant in North America, Brazil and Europe [4]. Blunt and cutting wounds on the head and neck are also common [ $\underline{5}]$.

Maxillofacial injuries stemming from IPV are difficult to investigate. Legal underreporting is common due to associations with alcohol abuse, illicit drug use, firearms and acts of violence against women, children, and the elderly, which generate fear, shame, low selfesteem and a sense of powerlessness []].

Facial fractures associated to IPV have functional, aesthetic and psychological effects on the victims, as well as a socioeconomic impact on the health systems of many countries [7]. These victims are more likely to suffer from depression, anxiety and post-traumatic stress disorder []]. Epidemiological studies help to identify demands, develop prevention programs and structure an integrated care system. The aim of this retrospective study was to compare the peculiarities of maxillofacial injuries caused by interpersonal violence with other etiologic factors.

\section{MATERIAL AND METHODS}

This retrospective study involved data collected from clinical notes and surgical records of patients treated at seven different hospitals located in three different cities in São Paulo state, Brazil. The sample was selected based on analysis of medical records of facial trauma patients attended by the Department of Oral and Maxillofacial Surgery in the Piracicaba Dental School at the University of Campinas from January 1999 to December 2012. A standardized form was designed to investigate the epidemiologic features of maxillofacial traumas, considering aspects such as age, gender, diagnosis, soft tissue lesions, facial injuries and general injuries. The exclusion criterion was incomplete information about the type of trauma on the medical chart. The origin of the facial trauma was classified as follows: traffic accidents (automobile and motorcycle); work accidents; sport accidents; falls; interpersonal violence; cycling accidents; pedestrian accidents and others. Facial injury sites were classified as follows: upper (frontal bone); middle (maxilla, nasal bones, zygomaticorbital complex, naso-orbital ethmoidal) and lower (mandible). In addition, dentoalveolar fractures and facial trauma without fractures were addressed. Mandibular fractures were described according to the anatomic site: condylar fractures; angle fractures; body fractures and fractures of symphysis. Abrasions and lacerations were classified as soft tissue injuries. The present study was approved by the Research Ethics Committee of Piracicaba Dental School, State University of Campinas (FOP/UNICAMP) under protocol number 75/2013.

\section{Statistical analysis}

Data were submitted to statistical analysis (simple descriptive statistics and Chi-squared test) with the support of the Statistical Package for Social Sciences (SPSS 18.0 for Windows, SPSS Inc, Chicago, IL). Binary logistic regression and the Chi-square test were performed and the results were considered relevant when $\mathrm{P}<0.05$. Frequency statistics were the main descriptive statistics used. These included absolute frequencies (raw counts) and relative frequencies (proportions or percentages of the total number of observations).

\section{RESULTS}

Based on the 13-year study period, 3,724 patient referrals to the Maxillofacial Surgery Department were enrolled in the present study.

Table 1. Distribution of patients with facial injuries according to etiological factors

\begin{tabular}{l|c}
\hline \multicolumn{1}{c|}{ Etiological factor } & N (\%) \\
\hline Falls & $822(22.1 \%)$ \\
\hline Cycling accidents & $646(17.3 \%)$ \\
\hline Interpersonal violence & $612(16.4 \%)$ \\
\hline Motor vehicle traffic accidents - motorcycle & $483(13 \%)$ \\
\hline Motor vehicle traffic accidents - automobile & $437(11.7 \%)$ \\
\hline Sports-related injuries & $229(6.1 \%)$ \\
\hline Pedestrian accidents & $163(4.4 \%)$ \\
\hline Work-related accidents & $132(3.5 \%)$ \\
\hline Others & $200(5.4 \%)$ \\
\hline Total & $3724(100 \%)$ \\
\hline
\end{tabular}

$\mathrm{N}=$ number of patients. 
Table 2. Distribution of facial injury diagnoses among a general sample and patients whose facial injury was associated with interpersonal violence (IPV)

\begin{tabular}{l|c|c|c|c}
\hline \multirow{2}{*}{\multicolumn{1}{c|}{ Diagnosis }} & \multicolumn{2}{c}{ General sample } & \multicolumn{2}{c}{ IPV } \\
\cline { 2 - 5 } & $\mathbf{N}$ & $\mathbf{\%}$ & $\mathbf{N}$ & $\mathbf{\%}$ \\
\hline Facial injury without fracture & 1337 & 35.8 & 176 & 28.8 \\
\hline Mandibular fracture & 662 & 17.8 & 149 & 24.3 \\
\hline Zygomatic-orbital complex fractures & 598 & 16.1 & 111 & 18.2 \\
\hline Dentoalveolar fracture & 488 & 13.1 & 35 & 5.7 \\
\hline Nasal bone fractures & 397 & 10.7 & 105 & 17.1 \\
\hline Mandibular and zygomatic-orbital complex fractures & 51 & 1.4 & 9 & 1.5 \\
\hline Maxillary fractures & 48 & 1.3 & 9 & 1.5 \\
\hline Mandible and maxillary fractures & 26 & 0.7 & 2 & 0.3 \\
\hline Frontal fracture & 22 & 0.6 & 1 & 0.2 \\
\hline Panfacial fractures & 24 & 0.6 & 4 & 0.7 \\
\hline Maxillary bones and zygomatic-orbital complex fractures & 23 & 0.6 & 1 & 0.2 \\
\hline Nasal bones and zygomatic-orbital complex fractures & 21 & 0.6 & 5 & 0.8 \\
\hline Naso-orbitoethmoid fracture & 14 & 0.4 & 2 & 0.2 \\
\hline Frontal and zygomatic-orbital complex fractures & 13 & 0.3 & 3 & 0.5 \\
\hline & 3724 & $100 \%$ & 612 & $100 \%$ \\
\hline
\end{tabular}

$\mathrm{N}=$ number of patients.

The median age at the time of admission was 29.2 years, with a standard deviation of 17.06 years. Of this total, $2792(75 \%)$ were male. Table 1 displays the distribution of etiologic factors in patients with facial injuries. A total of 612 patients (16.4\%) exhibited facial injuries related to IPV. In this group, male victims prevailed with $81 \%(\mathrm{n}=496)$ and the mean age was 31.28 years, with a standard deviation of 13.33 years. Weekly consumption of alcohol was reported by $32.4 \%$ and tobacco use was $43.8 \%$. In total, 79 patients $(12.8 \%)$ reported using non-injecting illicit drugs and $14(2.2 \%)$ stated that they currently used injecting drugs. In 176 cases, the facial injury did not result in a bone fracture. Isolated alveolar-dental injuries were observed in 35 patients. With regards to maxillofacial fractures, the mandible was the most affected bone (149 patients). Table 2 shows the distribution of diagnoses in the general sample and among patients who were victims of physical assault.

In the cases of mandibular fractures, the anatomic regions most affected were the body and the mandibular angle, with 36 cases in each region, followed by the condyle (25 cases), symphysis (9 cases) and isolated mandibular ramus (2 cases). In 41 patients, fractures involving more than one anatomic region of the mandible were observed. Lacerations and abrasions on the face were identified in 181 and 105 patients, respectively. Injuries to other body regions were observed in 146 (23.9\%) patients.
Table 3. Distribution of body injuries among patients with facial trauma and patients whose facial injury was associated with interpersonal violence (IPV)

\begin{tabular}{l|c|c|c|c}
\hline \multirow{2}{*}{ Location } & \multicolumn{2}{|c|}{ General sample } & \multicolumn{2}{c}{ IPV } \\
\cline { 2 - 5 } & $\mathbf{N}$ & $\mathbf{\%}^{\mathrm{a}}$ & $\mathbf{N}$ & $\mathbf{\%}^{\mathrm{b}}$ \\
\hline Upper limb & 774 & $19.4 \%$ & 59 & $9.6 \%$ \\
\hline Lower limb & 521 & $14.0 \%$ & 27 & $4.4 \%$ \\
\hline Neurocranium & 335 & $9 \%$ & 72 & $11.8 \%$ \\
\hline Thorax/chest & 267 & $7.2 \%$ & 42 & $6.9 \%$ \\
\hline Neck & 89 & $2.4 \%$ & 15 & $2.5 \%$ \\
\hline Abdomen & 84 & $2.3 \%$ & 17 & $2.8 \%$ \\
\hline
\end{tabular}

${ }^{a}$ The calculation is based on whole sample $(\mathrm{n}=3724)$.

${ }^{\mathrm{b}}$ The calculation is based on patients that involved with IPV $(n=612)$. $\mathrm{N}=$ number of patients.

Table 3 displays the distribution of body injuries in these patients, when compared to the general sample. There were several statistically significant differences between the total sample and IVP patients. Table 4 summarizes these results. Male victims were more prevalent for this etiologic factor.

A greater number of fractures and lacerations of the face was observed, although with fewer facial abrasions. With regards to the area of bone fractures, mandibular and nasal fractures were more prevalent and statistical differences were found. Fewer injuries occurred in other regions of the body, mainly due to fewer injuries of the upper and lower limbs. However, patients that were associated with IPV exhibited a greater number of injuries to the neurocranium. 
Table 4. Comparison of features of facial injury of victims of interpersonal violence (IPV) and other etiologic factors

\begin{tabular}{|c|c|c|c|c|c|c|}
\hline \multicolumn{7}{|c|}{ Independent variable } \\
\hline \multirow{2}{*}{\multicolumn{2}{|c|}{ Dependent variable }} & \multicolumn{3}{|c|}{ Patients with facial injury due to IPV } & \multirow{4}{*}{$\begin{array}{c}\chi^{2} \\
14.39\end{array}$} & \multirow[b]{2}{*}{$\mathbf{P}$} \\
\hline & & $\begin{array}{c}\text { Yes } \\
\mathbf{N}\end{array}$ & $\begin{array}{c}\text { No } \\
\text { N }\end{array}$ & $\begin{array}{c}\text { Total } \\
\mathbf{N}\end{array}$ & & \\
\hline \multirow{2}{*}{ Gender } & Male & 496 & 2296 & 2792 & & -10 \\
\hline & Female & 116 & 816 & 932 & & -0.001 \\
\hline \multirow{2}{*}{ Bone fracture } & Yes & 436 & 1956 & 2392 & \multirow{2}{*}{15.66} & \multirow{2}{*}{$<0.001$} \\
\hline & No & 176 & 1156 & 1332 & & \\
\hline \multirow{2}{*}{ Facial lacerations } & Yes & 181 & 1315 & 1496 & \multirow{2}{*}{33.97} & \multirow{2}{*}{$<0.001$} \\
\hline & No & 430 & 1796 & 2226 & & \\
\hline \multirow{2}{*}{ Abrasions } & Yes & 105 & 1045 & 1150 & \multirow{2}{*}{64.62} & \multirow{2}{*}{$<0.001$} \\
\hline & No & 507 & 2067 & 2574 & & \\
\hline \multirow{2}{*}{ Mandibular fracture } & Yes & 149 & 463 & 662 & \multirow{2}{*}{21.62} & \multirow{2}{*}{$<0.001$} \\
\hline & No & 513 & 2599 & 3062 & & \\
\hline \multirow{2}{*}{ Nose fracture } & Yes & 106 & 291 & 397 & \multirow{2}{*}{34.1} & \multirow{2}{*}{$<0.001$} \\
\hline & No & 506 & 2821 & 3327 & & \\
\hline \multirow{2}{*}{ Body injury } & Yes & 146 & 1009 & 1155 & \multirow{2}{*}{17.54} & \multirow{2}{*}{$<0.001$} \\
\hline & No & 466 & 2103 & 2569 & & \\
\hline \multirow{2}{*}{ Neurocranium injury } & Yes & 72 & 263 & 335 & \multirow{2}{*}{6.85} & \multirow{2}{*}{$<0.01$} \\
\hline & No & 540 & 2849 & 3389 & & \\
\hline \multirow{2}{*}{ Upper limb } & Yes & 59 & 665 & 724 & \multirow{2}{*}{44.95} & \multirow{2}{*}{$<0.001$} \\
\hline & No & 553 & 2446 & 2999 & & \\
\hline \multirow{2}{*}{ Lower limb } & Yes & 27 & 494 & 521 & \multirow{2}{*}{55.84} & \multirow{2}{*}{$<0.001$} \\
\hline & No & 585 & 2618 & 3203 & & \\
\hline
\end{tabular}

$\mathrm{N}=$ number of patients; $\chi^{2}=$ Chi-square.

Binary logistic regression was performed to determine whether fractures in facial injuries were affected by gender, age (median 30 years), drug use, the presence of lacerations or the presence of abrasions. Fractures were associated with gender: male patients are more at risk than females $(\mathrm{OR}=1.61, \mathrm{P}<0.002,95 \% \mathrm{CI}: 1.05$ to 2.46$)$.

\section{DISCUSSION}

Although motor vehicle accidents are still the main cause of maxillofacial fractures in some developing countries, recent data from developed countries have shown that IPV is the dominant cause [9]. IPV is one of the leading causes of maxillofacial fractures and its prevalence in a population varies according to geographic region and appears to be associated with factors such as socioeconomic status, population density and age characteristics [10]. The prevalence of male victims has been reported in most studies, ranging from $61 \%$ to $92 \%$, as well as a mean age of approximately 30 years [10-14]. Similar results were found in the present study.
The peak incidence of maxillofacial injury due to IPV was observed in young adults. However, children are also affected and several studies have reported the patterns and severity of these injuries $[15,16]$. This age group is susceptible to craniofacial trauma due to their greater cranial mass-to-body weight ratio. Compared to adults, less is known about pediatric craniofacial trauma [17]. In the present study, 65 patients were under 18 years of age, although most of them (36 patients) were aged between 16 and 18 years. These patients mainly exhibited nasal bone (21 patients) and mandibular fractures (12 patients), results which are in accordance with the literature [16].

The prevalence of male victims is influenced by cultural models of gender, defined as the set of attributes, values, roles and behavior patterns that are expected from a man in a particular culture. Generally, the traits valued in this socialization are aggression, domination and exploitation of danger, which could contribute to their association with IPV. IPV among females is mainly associated with domestic violence [15]. In the present study, it was not possible to determine the pattern of 
violence suffered. When the victim is female, the case should be investigated regardless of the site of the injury, as there is a greater possibility that they are the victim of physical aggression due to the vulnerability of the gender [8]. Another relevant factor is the differences in female participation in social activities, making them more (or less) prone to urban violence [12]. Whether the injury type, location and mechanism also differ between genders remains controversial $[13,16]$.

Patients who were victims of physical assault, unlike other etiologies such as sports accidents, are often affected by problems such as drug use and poverty [13]. In the present study, we found high consumption rates of alcohol, tobacco and noninjecting drugs. Alcohol is a known depressant of the central nervous system. Its consumption results in an increase in confidence, followed by the subjective feeling of increased mental and physical capacity, as well as impaired judgment and coordination. These physiological effects explain the increased incidence of IPV among these patients $[\underline{6}, \underline{10}]$.

Lee et al. [9] found that alcohol was involved in $87 \%$ of maxillofacial fractures caused by IPV, compared with $58 \%$ for motor vehicle accidents. Studies have reported that fractures of the mandible are the most prevalent, followed by zygomatic complex fractures [17-19]. Similar results were found in the present study. Furthermore, we showed that the prevalence of mandibular and nasal bone fractures was higher in this group of patients.

The literature indicates that trauma associated with IPV are less severe than those associated with other etiological factors due to the magnitude and speed of impact. Despite this fact, patients in which IPV was the etiologic factor exhibited a higher prevalence of bone fractures when compared to all other patients treated. Possibly, some patients with minor injuries do not seek medical care due to shame or fear. This could increase the percentage of bone fractures within this etiological factor. A high frequency of soft tissue lesions were found on the face, particularly lacerations. In the literature, the most common orofacial injuries are lip injuries, followed by other soft tissue injuries on the face, gingival and oral mucosa injuries, and teeth and/ or periodontal injuries [12]. The pattern of facial fractures is related to the type, direction and force of impact, as well as the anatomical features of the area. IPV injuries are usually caused by punches or kicks, for which the face is the main target region [13]. The face is probably the target for most acts of physical aggression as it is easily reached, due to its location at the same height as the aggressor's raised arm.
It has also been suggested that the aggressor either consciously or unconsciously wishes to affect the victim's self-esteem [8]. Males appear to be injured by more dangerous mechanisms and are more frequently injured by objects than females $[14,16]$. The mandible, which is mobile and prominent on the face, is more susceptible to trauma. In the present study, the mandibular body was the area most commonly affected by fracture. The region of the mandibular angle has been considered the least resistant, mainly due to the presence of the mandibular third molar. Significantly, most individuals involved in this type of fracture are young [20].

The most severe maxillofacial injuries are typically associated with motor vehicle accidents. These accidents often cause pan-facial, cranial, orthopedic, abdominal and cervical spine injuries, which may require multidisciplinary input, with significant interventions such as intubation, craniotomy and tracheostomy $[21,22]$. Conversely, IPV tends to be associated with isolated fractures, particularly in the mandibular region [9]. The present study confirmed that most patients were affected by a fracture in only one region of the face. A lower prevalence of injuries was recorded for other parts of body. The neurocranium was more affected by this etiologic factor.

Although the World Health Organization considers the response of health-care services to victims of violence to be an international priority, health professionals are generally not qualified to identify the injuries or council victims. They are restricted to treating the injuries. The role of health professionals is to identify the etiology of the injury and, in cases of physical aggression, provide the victim with information on where to seek help. Moreover, health professionals are not well prepared to ask sensitive questions and are unaware of victim-support institutions [8].

\section{CONCLUSIONS}

The findings of the present study demonstrated that facial trauma caused by interpersonal violence seem to be associated with a higher rate of facial fractures and lacerations when compared to all other patients with facial injuries. Male patients are more likely to exhibit severe injuries and exhibited a greater amount of bone fractures. Prominent areas of the face and neurocranium should be carefully examined as they tend to be more prone to injuries. 


\section{ACKNOWLEDGMENTS AND DISCLOSURE STATEMENTS}

The authors would like to thank Dr. Glaucia Maria Bovi Ambrosano, Associate Professor, Department of
Community Dentistry, Campinas State University Piracicaba Dental School, for statistical analysis assistance.

The authors declare that there is no conflict of interest related to this study.

\section{REFERENCES}

1. Roberts I, Shakur H, Edwards P, Yates D, Sandercock P. Trauma care research and the war on uncertainty. BMJ. 2005 Nov 12;331(7525):1094-6. [Medline: 16282383] [PMC free article: 1283261]

2. Gassner R, Tuli T, Hächl O, Rudisch A, Ulmer H. Cranio-maxillofacial trauma: a 10 year review of 9,543 cases with 21,067 injuries. J Craniomaxillofac Surg. 2003 Feb;31(1):51-61. [Medline: 12553928] [doi: 10.1016/S1010-5182(02)00168-3]

3. Lee KH. Interpersonal violence and facial fractures. J Oral Maxillofac Surg. 2009 Sep;67(9):1878-83. [Medline: 19686924] [doi: 10.1016/j.joms.2009.04.117]

4. Boffano P, Kommers SC, Karagozoglu KH, Forouzanfar T. Aetiology of maxillofacial fractures: a review of published studies during the last 30 years. Br J Oral Maxillofac Surg. 2014 Dec;52(10):901-906. Epub 2014 Sep 15. Review. [Medline: 25218316] [doi: 10.1016/j.bjoms.2014.08.007]

5. Downing A, Cotterill S, Wilson R. The epidemiology of assault across the West Midlands. Emerg Med J. 2003 Sep;20(5):434-7. Emerg Med J 2003;20:434-7. [Medline: 12954682] [PMC free article: 1726169] [doi: 10.1136/emj.20.5.434]

6. O'Meara C, Witherspoon R, Hapangama N, Hyam DM. Alcohol and interpersonal violence may increase the severity of facial fracture. Br J Oral Maxillofac Surg. 2012 Jan;50(1):36-40. Epub 2010 Dec 9. [Medline: 21145631] [doi: 10.1016/j.bjoms.2010.11.003]

7. Joy D, Probert R, Bisson JI, Shepherd JP. Posttraumatic stress reactions after injury. J Trauma. 2000 Mar;48(3):490-4. [Medline: 10744290] [doi: 10.1097/00005373-200003000-00020]

8. Ferreira MC, Batista AM, Ferreira Fde O, Ramos-Jorge ML, Marques LS. Pattern of oral-maxillofacial trauma stemming from interpersonal physical violence and determinant factors. Dent Traumatol. 2014 Feb;30(1):15-21. Epub 2013 May 15. [Medline: 23675634] [doi: 10.1111/edt.12047]

9. Lee KH, Snape L, Steenberg LJ, Worthington J. Comparison between interpersonal violence and motor vehicle accidents in the aetiology of maxillofacial fractures. ANZ J Surg. 2007 Aug;77(8):695-8. [Medline: 17635287] [doi: 10.1111/j.1445-2197.2007.04189.x]

10. Eggensperger N, Smolka K, Scheidegger B, Zimmermann H, Iizuka T. A 3-year survey of assault-related maxillofacial fractures in central Switzerland. J Craniomaxillofac Surg. 2007 Apr;35(3):161-7. Epub 2007 Jun 20. [Medline: 17583524] [doi: 10.1016/j.jcms.2007.01.002]

11. Lee KH, Snape L, Steenberg LJ, Worthington J. Comparison between interpersonal violence and motor vehicle accidents in the aetiology of maxillofacial fractures. ANZ J Surg. 2007 Aug;77(8):695-8. [Medline: 17635287] [doi: 10.1111/j.1445-2197.2007.04189.x]

12. Caldas IM, Magalhães T, Afonso A, Matos E. The consequences of orofacial trauma resulting from violence: a study in Porto. Dent Traumatol. 2010 Dec;26(6):484-9. [Medline: 21078073] [doi: 10.1111/j.1600-9657.2010.00936.x]

13. Salonen EM, Koivikko MP, Koskinen SK. Violence-related facial trauma: analysis of multidetector computed tomography findings of 727 patients. Dentomaxillofac Radiol. 2010 Feb;39(2):107-12. [Medline: 20100923] [PMC free article: 3520202] [doi: 10.1259/dmfr/67015359]

14. Businger AP, Krebs J, Schaller B, Zimmermann H, Exadaktylos AK. Cranio-maxillofacial injuries in victims of interpersonal violence. Swiss Med Wkly. 2012 Oct 9;142:w13687. [Medline: 23135921] [doi: 10.4414/smw.2012.13687]

15. Hoppe IC, Kordahi AM, Paik AM, Lee ES, Granick MS. Pediatric facial fractures as a result of gunshot injuries: an examination of associated injuries and trends in management. J Craniofac Surg. 2014 Mar;25(2):400-5. [Medline: 24561367] [doi: 10.1097/SCS.00000000000000657]

16. Hoppe IC, Kordahi AM, Paik AM, Lee ES, Granick MS. Examination of life-threatening injuries in 431 pediatric facial fractures at a level 1 trauma center. J Craniofac Surg. 2014 Sep;25(5):1825-8. [Medline: 25203578] [doi: $10.1097 /$ SCS.0000000000001055]

17. Mericli AF, DeCesare GE, Zuckerbraun NS, Kurland KS, Grunwaldt L, Vecchione L, Losee JE. Pediatric craniofacial fractures due to violence: comparing violent and nonviolent mechanisms of injury. J Craniofac Surg. 2011 Jul;22(4):13427. [Medline: 21772183] [doi: 10.1097/SCS.0b013e31821c944c]

18. Le BT, Dierks EJ, Ueeck BA, Homer LD, Potter BF. Maxillofacial injuries associated with domestic violence. J Oral Maxillofac Surg. 2001 Nov;59(11):1277-83; discussion 1283-4. [Medline: 11688025] [doi: 10.1053/joms.2001.27490]

19. Arosarena OA, Fritsch TA, Hsueh Y, Aynehchi B, Haug R. Maxillofacial injuries and violence against women. Arch Facial Plast Surg. 2009 Jan-Feb;11(1):48-52. [Medline: 19153293] [doi: 10.1001/archfacial.2008.507] 
20. Kieser J, Stephenson S, Liston PN, Tong DC, Langley JD. Serious facial fractures in New Zealand from 1979 to 1998 . Int J Oral Maxillofac Surg. 2002 Apr;31(2):206-9. [Medline: 12102421] [doi: 10.1054/ijom.2002.0208]

21. Adeyemo WL, Ladeinde AL, Ogunlewe MO, James O. Trends and characteristics of oral and maxillofacial injuries in Nigeria: a review of the literature. Head Face Med. 2005 Oct 4;1:7. Review. [Medline: 16270942] [PMC free article: 1277015] [doi: 10.1186/1746-160X-1-7]

22. Brasileiro BF, Passeri LA. Epidemiological analysis of maxillofacial fractures in Brazil: a 5-year prospective study. Oral Surg Oral Med Oral Pathol Oral Radiol Endod. 2006 Jul;102(1):28-34. Epub 2006 Mar 22. [Medline: 16831669] [doi: 10.1016/j.tripleo.2005.07.023]

23. Rajkumar K, Ramen S, Chowdhury R, Chattopadhyay PK. Mandibular third molars as a risk factor for angle fractures: a retrospective study. J Maxillofac Oral Surg. 2009 Sep;8(3):237-40. doi: 10.1007/s12663-009-0058-z. Epub 2009 Nov 21. [Medline: 23139516] [PMC free article: 3454229] [doi: 10.1007/s12663-009-0058-z]

24. Yokoyama T, Motozawa Y, Sasaki T, Hitosugi M. A retrospective analysis of oral and maxillofacial injuries in motor vehicle accidents. J Oral Maxillofac Surg. 2006 Dec;64(12):1731-5. [Medline: 17113438] [doi: 10.1016/i.joms.2005.11.104]

\section{To cite this article:}

Goulart DR, Colombo LA, de Moraes M, Asprino L. What Is Expected from a Facial Trauma Caused by Violence?

J Oral Maxillofac Res 2014;5(4):e4

URL: http://www.ejomr.org/JOMR/archives/2014/4/e4/v5n4e4ht.pdf

doi: $10.5037 /$ jomr.2014.5404

Copyright (C) Goulart DR, Colombo LA, de Moraes M, Asprino L. Published in the JOURNAL OF ORAL \& MAXILLOFACIAL RESEARCH (http://www.ejomr.org), 29 December 2014.

This is an open-access article, first published in the JOURNAL OF ORAL \& MAXILLOFACIAL RESEARCH, distributed under the terms of the Creative Commons Attribution-Noncommercial-No Derivative Works 3.0 Unported License, which permits unrestricted non-commercial use, distribution, and reproduction in any medium, provided the original work and is properly cited. The copyright, license information and link to the original publication on (http://www.ejomr.org) must be included. 